УДК 691.3

\title{
УМОВИ ФОРМУВАННЯ ДОДАТКОВИХ КРИСТАЛОГІДРАТІВ НА ПОВЕРХНІ ПОЛІЕФІРНОГО ВОЛОКНА
}

\author{
Інж. В.А. Арутюнов \\ УСЛОВИЯ ФОРМИРОВАНИЯ ДОПОЛНИТЕЛЬНЫХ КРИСТАЛЛОГИДРАТОВ НА \\ ПОВЕРХНОСТИ ПОЛИЭФИРНОГО ВОЛОКНА
}

\author{
Инж. В.А. Арутюнов \\ FORMATION CONDITIONS OF ADDITIONAL CRYSTALLINE HYDRATE ON THE SURFACE \\ OF POLYESTER FIBER
}

Engineer V.A. Arutyunov

Проаналізовано й експериментально доведено можливість застосування поліефірного волокна у иементних складах за умови додаткового введення хімічних сполук які сприятимуть синтезу додаткових кристалогідратів на поверхні поліефірного волокна, що вироблено на силіконових апретах, ие дасть змогу захистити поверхню волокна від лужного середовища порового електроліту цементного каменю.

Ключові слова: поліефірне волокно, иементний камінь,кристалічні сполуки.

Проанализирована и экспериментально доказана возможность применения полиэфирного волокна в иементных составах при дополнительном введении химических соединений, способствующих синтезу дополнительных кристаллогидратов на поверхности полиэфирного волокна, которое произведено на силиконовых аппретах, что позволит защитить поверхность волокна от щелочной среды порового электролита цеементного камня.

Ключевые слова: полиэфирное волокно, иементный камень, кристаллические соединения.

Analyzed and experimentally demonstrated the possibility of using a polyester fiber in cement compositions with the additional administration promotes the synthesis of chemical compounds on the surface of other crystalline polyester fiber, which will protect the surface of the fiber from the alkaline medium of the pore electrolyte cement stone. Silicones - a typically organic siloxane polymers. Organic groups may have a dipole moment on siloxane chain therefore provide hydrophilic silicone film and elektropoverhnevyy capacity, ie the ability to serve as a substrate for products of hydration of cement. The dipole moment is determined by the structure of syloksanovoy what causes polarization communication silicon hydrocarbon. Extremely flexible silicon circuit responds to the dipole moment and roztashuvuye siloxane link so that positively charged silicon single link located opposite the negatively charged oxygen atom of another link. The result is a kind of spiral structure. This structure allows organically embedded in the metrics arrays water structures, including solutions and chemicals introduced into the composition of cement for the synthesis of crystalline.

Keywords: polyester fiber, cement stone, crystalline compounds.

Вступ. На сьогодні для ремонту, захисту й гідроізоляції бетонних, залізобетонних $\mathrm{i}$ кам'яних конструкцій застосовуються сухі будівельні суміші 3 широким діапазоном захисних властивостей, у тому числі гідроізоляційні, рулонні матеріали, полімерні мастики, плівки та мембрани. Кожен 3 цих матеріалів має свої недоліки, що обмежують сфери їх застосування. Так, сухі суміші дають змогу влаштовувати захисно-гідроізоляційні шари, що мають високе зчеплення 3 поверхнями і витримують гідростатичний тиск будь-якого знака, як на притиск, так і на відрив. Проте ї механізоване нанесення (торкретування) потребує застосування спеціального обладнання, а нанесення вручну - 
високої кваліфікації і ретельного дотримання технології. Рулонні матеріали (полімерні плівки і мембрани, бентонітові мати) не потребують високої кваліфікації робітників, однак працюють лише при їх притиску тиском води, а при протилежному тиску води потребують улаштування притискної стінки i, як правило, не можуть виконувати несучих функцій.

Найбільш перспективними для ремонтних робіт бетонних, залізобетонних i кам'яних конструкцій $є$ композиційні матеріали на основі цементу, що працюють за принципом інтегрально-капілярної дії. Вони здатні не тільки зовні захищати конструкцію, але i формувати в поровому просторі контактного шару бетону конструкції ущільнений кристалічними новоутвореннями бар'єр, що перешкоджає фільтрації води як усередину конструкції, так і назовні. Тому отримання високоякісного матеріалу для ремонтних i гідроізоляційних робіт, що поєднує в собі корисні властивості сухих сумішей інтегрально-капілярної дії $\mathrm{i}$ рулонних матеріалів, $є$ актуальним завданням.

Завдання дослідження:

- проаналізувати теоретично й експериментально довести можливість поєднання поліефірного волокна у вигляді нетканого матеріалу об'ємної структури 3 цементною матрицею;

- експериментально обгрунтувати

введення хімічних сполук для синтезу додаткових кристалогідратів на поверхні поліефірного волокна, що дасть змогу захистити поверхню волокна від лужного середовища порового електроліту цементного каменю.

Методи дослідження. Методами рентгенофазового, диференційно-термічного аналізів та електронної мікроскопії досліджувалися продукти гідратації цементного каменю i мікроструктури композита.

Результати дослідження. У результаті проведених досліджень установлено, що поліефірне волокно на силіконовому апреті забезпечує здатність волокна служити підкладкою для продуктів гідратації цементу, що, 3 одного боку, захищає іiі поверхню від гідролізу в лужному середовищі, а 3 другого сприяє найкращому затисканню фібри в структурі цементного каменю (рис. 1).

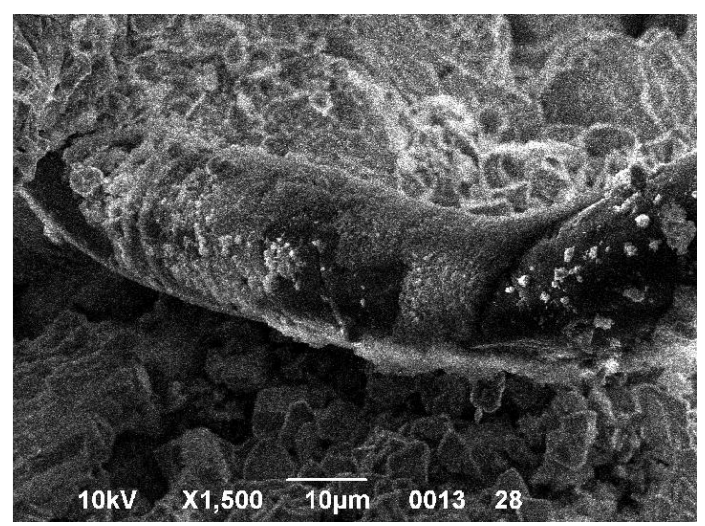

Рис. 1. Затискання поліефірного волокна в цементному камені через 28 діб тверднення, електронний мікрознімок

Силікони - це, як правило, органосилоксанові полімери (поліорганосилоксани) зі структурною формулою $\left[\mathrm{R}_{2} \mathrm{SiO}\right] \mathrm{n}$, де $\mathrm{R}$ - органічна група. Ці групи можуть мати дипольний момент щодо силоксанового ланцюга, отже, забезпечувати силіконовій плівці гідрофільність і електроповерхневий потенціал, тобто здатність служити підкладкою для продуктів гідратації цементу. Дипольний момент визначається будовою силоксанової групи, що саме викликає поляризацію зв'язку кремнію 3 вуглеводнем. Виключно гнучкий силоксановий ланцюг $\mathrm{Si}-\mathrm{C}$ i $\mathrm{Si}-\mathrm{O}$ реагуе на дипольний момент $\mathrm{i}$ «намагається» розташувати силоксанові ланки таким чином, щоб позитивно заряджений кремній однієї ланки розташовувався навпроти негативно зарядженого атома кисню іншої ланки. У результаті виникає своєрідна спіральна конструкція, запропонована М.М. Левицьким $[1,3]$. При цьому вуглеводневі радикали спрямовані назовні, а гідрофільні «головки» втягуються всередину (рис. 2).

Така будова дає змогу органічно вбудовуватися в метрики граток водним структурам, тому що, незважаючи на відмінності в будові «жирних хвостів» молекул i їх гідрофільних «головок», спостерігається закономірність у значеннях їх періодів.

B.I. Лобишев із співробітниками запропонував комп'ютерний модульний дизайн параметричних структур води. В об'ємі води основний структурний елемент, показаний на рис. 3, також утворюється не лінійним, а закрученим у спіраль, 3 кутовим параметром $132^{\circ}[2]$. 


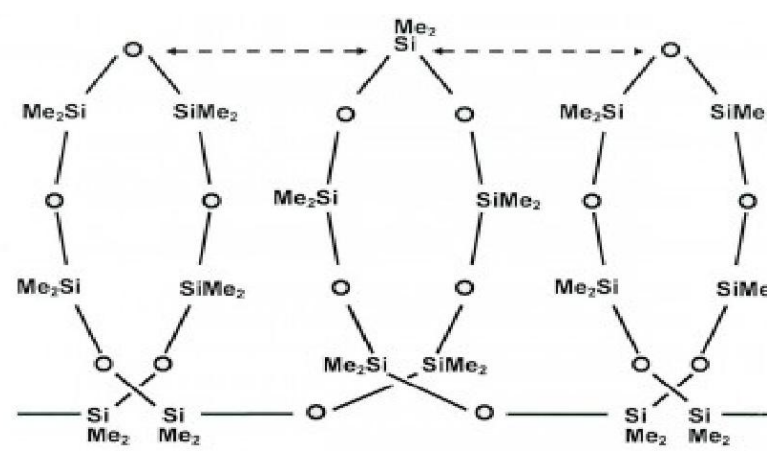

a

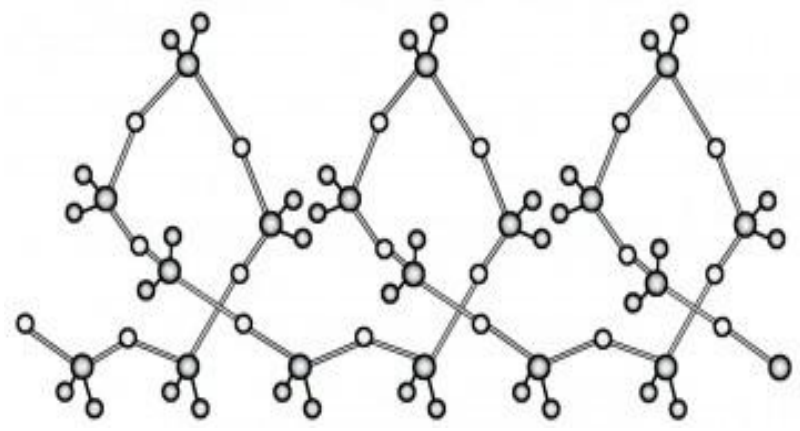

6

Рис. 2. Силоксановий ланцюг:

a - спіральна конструкція силоксанового ланцюга; б - об'ємна модель силоксанового ланцюга

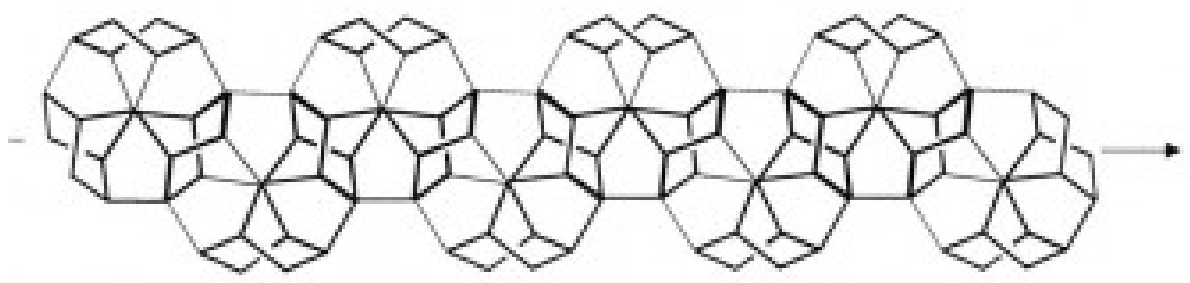

Рис. 3. Формування структури води, спіраль 30/11, вільні Н-зв'язки виділені жирним

При цьому системоутворююча ієрархічна структура води відіграє роль матриці або «будівельних риштувань» для самоорганізації просторових структур при формуванні кристалічної обойми на поверхні поліефірного волокна. Елементи збірки таких систематизованих структур подано на електронному знімку (рис. 4,a). При пересиченні водних плівок іонами в процесі гідратації цементу відбувається зростання кристалів на поверхні поліефірного волокна (рис. 4,б).

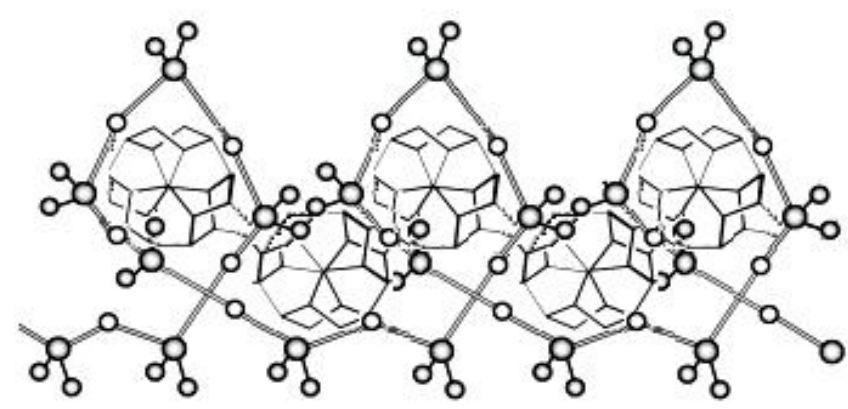

a

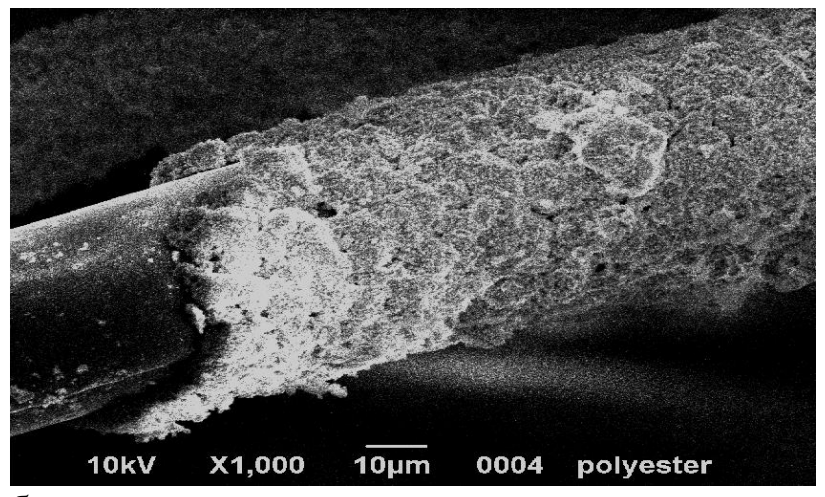

б

Рис. 4. Формування кристалічної обойми на силіконовій плівці поліефірного волокна: a - структурна модель силоксанового ланцюга 3 вбудованим спіралевидним структурним елементом води; б - зростання кристалічних структур на поверхні поліефірного волокна, обробленого силіконовим апретом 
Теоретично обгрунтовано i визначено склад комплексу хімічних сполук. На процеси структуроутворення великий вплив мають гідроксильні групи гідроксидів лужноземельних металів. Найбільший ефект при малих концентраціях досягається при спільній дії катіонів та однойменних гідроксидів, при якому коагуляційні зв'язки, що виникають, перетворюються в більш міцні конденсаційно-кристалізаційні структури. Такі структури мають високу міцність внаслідок безпосередніх фазових контактів між частинками. При цьому міцність зростає зі зменшенням пористості і розмірів часток не тільки через збільшення числа контактів, але i внаслідок меншої ймовірності наявності всередині частинок небезпечних дефектів.

Таким чином, твердження про те, що підвищити міцність зчеплення поліефірного фіброволокна 3 цементним каменем можна шляхом його обробки силанами, було підтверджено у роботі експериментально, методами електронної мікроскопії. На користь поліефірного волокна може свідчити і те, що його ціна менша у 5-10 разів по відношенню до інших полімерних волокон (табл. 1). Крім того, значна частина волокна переробляється із вторинної сировини (пластикових пляшок).

Ціни на різні волокна в порівнянні з поліефірним технічним волокном

Таблиця 1

\begin{tabular}{|c|l|c|}
\hline $\begin{array}{c}\text { № } \\
\text { п/п }\end{array}$ & \multicolumn{1}{|c|}{ Вид волокна } & Ціна у дол. США за 1 кг \\
\hline 1 & Поліефірні & 3 \\
\hline 2 & Високомолекулярний поліетилен & $14-17$ \\
\hline 3 & Вуглецеві волокна & $15-2000$ \\
\hline 4 & Скляні волокна & 3 \\
& Е-типу & 15 \\
& S-2-типу & 50 \\
\hline 5 & Поліпропіленові & 1000 \\
\hline 6 & Керамічні & \\
\hline
\end{tabular}

Розрахунковим шляхом було встановлено вплив мікроармуючих добавок на міцнісні і пружні властивості цементних композиційних матеріалів. Установлено, що наповнення цементної матриці мікроволокнами знижує модуль пружності композита до $30 \%$, що відповідно підвищуе його пластичні властивості і може служити демпфером у цементному камені (табл. 2).

Таблиця 2

Розрахункові значення модуля пружності і міцності цементних композитів з різними наповнювачами

\begin{tabular}{|c|c|c|c|c|c|}
\hline \multirow[t]{2}{*}{ Матеріал } & \multirow{2}{*}{$\begin{array}{c}\text { Модуль } \\
\text { пружності } \\
\text { наповнювача } \\
E, \text { МПа }\end{array}$} & \multirow{2}{*}{$\begin{array}{c}\text { Модуль } \\
\text { пружності } \\
\text { композита } E, \\
\text { МПа }\end{array}$} & \multirow{2}{*}{$\begin{array}{c}\text { Міцність композита } \\
\text { при стиску } R, \\
\text { кгс/см }(\text { МПа) }\end{array}$} & \multicolumn{2}{|c|}{ Відносний об’єм } \\
\hline & & & & $\begin{array}{l}\text { цемент- } \\
\text { ного } \\
\text { каменю } \\
V_{\mathrm{T}}\end{array}$ & $\begin{array}{c}\text { запов- } \\
\text { нювача } \\
V_{м 2}\end{array}$ \\
\hline $\begin{array}{l}\text { Поліпропіленове } \\
\text { волокно }\end{array}$ & 3600 & 17180 & $144,82(14,48)$ & 0,7 & 0,3 \\
\hline Поліефірне волокно & 8500 & 18650 & $175,28(17,53)$ & 0,7 & 0,3 \\
\hline Скляне волокно & 8000 & 18500 & $172,04(17,20)$ & 0,7 & 0,3 \\
\hline Кварцовий пісок & 45000 & 29600 & $493,55(49,36)$ & 0,7 & 0,3 \\
\hline Цементний камінь & 23000 & 23000 & $282,42(28,24)$ & 0,7 & 0,3 \\
\hline
\end{tabular}


Застосування поліефірних волокон по відношенню до поліпропіленових більш перспективне, оскільки на поліпропіленових волокнах, за даними, отриманими у ході експерименту, не спостерігалося зростання кристалогідратів (рис. 5) на відміну від поліефірних (рис. 4). Кристалічна обойма на поліефірному волокні захищає його поверхню від гідролізу і сприяє спільній роботі цементної матриці і волокна, що підвищує деформативноміцнісні і гідрофізичні показники цементних композитів.

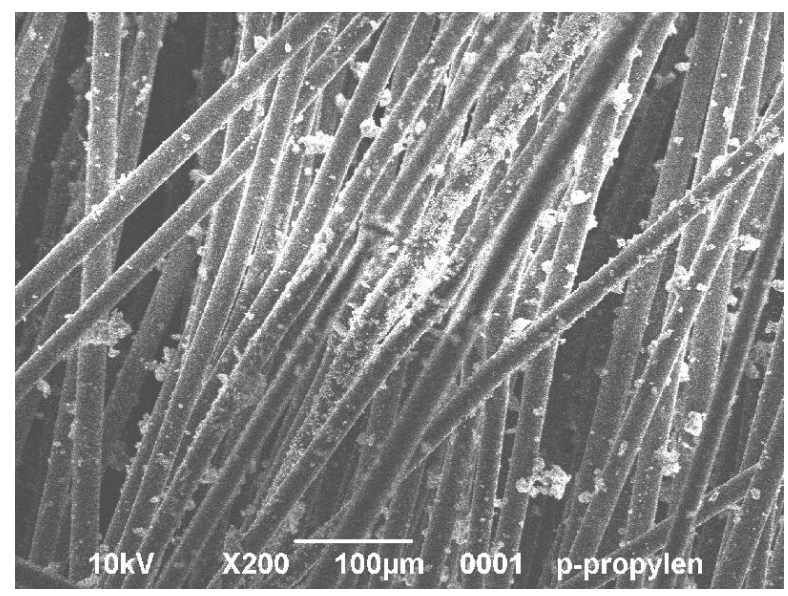

Рис. 5. Електронно-мікроскопічні знімки поліпропіленового волокна з витяжки цементного складу інтегрально-капілярної дії на 28 добу твердіння

Висновок. Доведена можливість введення поліефірного армуючого компонента в цементну матрицю; теоретично обгрунтовано і визначено склад комплексу хімічних сполук, що надають можливість отримати додаткові кристалічні фазові структури на поверхні поліефірного волокна, подібні за походженням до кристалогідратів цементного каменю.

\section{Список використаних джерел}

1. Левицкий, M.M. Многоликие силоксаны - URL [Электронный ресурс] / M.M. Левицкий. Режим доступа: http://him.1september.ru/ 2003/45/1.htm.

2. Лобышев, В.И. Компьютерный модульный дизайн параметрических структур воды [Текст] / В.И. Лобышев, А.Б. Соловей, Н.А. Бульенков // Биофизика, 2003. - Т. 47. - С. 1011-1021.

3. Гончарова, Г.Ю. Новый подход к выбору соединений для направленного воздействия на свойства ледовых поверхностей [Электронный ресурс] / Г.Ю. Гончарова. - Режим доступа: http://ice4sport.com/d/660339/d/4_4.jpg.

Рецензент д-р техн. наук, професор А.А. Плугін

Арутюнов Валерій Ашотович, здобувач кафедри будівельних матеріалів та виробів Харківського національного університету будівництва та архітектури. Тел.: (057)706-20-73. E-mail: kstuca.bmiv@gmail.com.

Arutyunov Valery Ashotovich, postgraduate, department building materials and products Kharkiv National Universitu of Civil Engineering and Architecture. Tel. (057) 706-20-73. E-mail. kstuca.bmiv@gmail.com.

Стаття прийнята 11.12.2015 p. 